\title{
Ownership Structure and Debt Policy: Evidence in Property and Real Estate Company
}

\author{
Abel Tasman ${ }^{1}$, Erni Masdupi ${ }^{2}$, Syawalia Safitri ${ }^{3}$ \\ ${ }^{1}$ Universitas Negeri Padang, Padang Indonesia, $₫$ abeltasman@fe.unp.ac.id \\ ${ }^{2}$ Universitas Negeri Padang, Padang Indonesia, $\square$ emasdupi@gmail.com \\ ${ }_{3}^{3}$ Universitas Negeri Padang, Padang Indonesia, $\square$ syawaliasafitri8@gmail.com
}

\begin{abstract}
In carrying out its operational activities, a company will greatly depend on its funding sources, namely internal funding, and external funding. Debt policy is one of the risky external funding sources. This study aims to see the relationship between insider ownership and institutional ownership with the debt policy of property and real estate companies listed on the Indonesia Stock Exchange in 2012-2015. The sample was chosen based on purposive sampling. To get results that can better explain the phenomenon, this study uses several control variables, namely dividend payment, firm size, asset structure, profitability, and tax rate. The data analysis technique used in this study is the partial correlation. The results of this study indicate that insider ownership and institutional ownership have no correlation with debt policy in property and real estate companies listed on the Indonesia Stock Exchange
\end{abstract}

Keywords: Debt Policy, Ownership Structure, Insider Ownership, Institutional Ownership

\section{Introduction}

Financial management aims to maximize the well-being of the owners (shareholders) through three decisions, investment decisions, financial decisions, and dividend policy. The investment decision of the company is an important decision related to the survival of the company later. Generally, there are two forms of investment sources at the company that is internal and external funding sources. Source of internal funds, which can be obtained from the company as retained earnings, whereas external funds are derived from outside the company, such as long-term debt, it will be associated with a policy of corporate debt (Bambang, 1996: 220).

According to Brigham (2011: 150), most large-scale companies which choose to do its operations by using debt, since it can press interest expense in the determination of tax (deductible), thereby it makes the real cost of debt low. Besides, companies that use debt will be trusted by market investors because they have the ability and looks a good prospect.

According to Husnan (2008: 253) debt policy is a company management actions will fund the company's operations by using capital from debt. Debt is another mechanism that can be used to control the agency conflict (Erni,2005). According to Jensen (1976) with debt will be able to control the use of free cash flow in excess by management, will thus be able to avoid wasted investment. According to Brigham and Houston (2011: 188) factors that affect the stability of the debt policy namely sale, ownership structure, asset structure, growth rate, profitability, management, financial flexibility, market conditions and internal conditions of the company.

Property and real estate is the large-scale enterprises and growing in Indonesia, the company uses debt to do its operations activities. Besides, the company property is the company has fixed assets of more than current assets so it will make company assets as collateral, and according to Keown (2008: 83) companies with tangible assets such as buildings and land can finance their assets with debt.

According to Brigham and Houston (2011: 188), many factors that affect debt policy. A factor or variable has a different effect on the debt policy, which can be positive or negative effect. This research will be focused on the relationship of ownership structure which is insider ownership and institutional ownership with debt policy. The first factor has a relationship with debt policy is insider ownership. Insider ownership represents the percentage of the ownership of shares by the 
management. According to Jensen and Meckling (1976) explains that insider ownership is one way that can be used for problem agency. According to Keown (2008: 18), the agency problem is the problems arising from conflicts of interest between managers (agents of shareholders) to shareholders.

According to Wahidahwati (2001) in Abdullah (2009), the managerial within a company is a party that actively play a role to decide on the company. The first theory which associated with insider ownership is agency theory. According to Pearce and Robinson (2007: 47) agency theory is the idea to control organization that is based on the argument that the separation of ownership with management will cause the owner's interest will be ignored. When the owner (or manager) have delegated decision-making authority on the manager, there is an agency relationship between them. Agency relationship between shareholders and managers will be effective if managers make investment decisions that are consistent with the interests of shareholders. However, when the interests of managers are not equal to the interests of the owner, then the decision taken by the manager will most likely reflect the preferences of the manager than the owner.

According to Devi and Force (2008), increased insider ownership will force managers to bear the risk as a consequence. Insider ownership also improves the firm performance and the manager will use the optimal debt because of managers also as shareholders. Companies that use non-optimal debt will pose a great risk to the company and also have a direct impact on managers as shareholders. This shows that the increase in insider ownership will decrease company debt.

The second factor that has a relationship with debt policy is institutional ownership. Institutional ownership is the percentage of share ownership by institutional investors such as investment firms, banks, insurance companies as well as possession of institutions and other companies (Wahidahwati, 2001) in (Abdullah, 2009). According to Abdullah (2009) ownership by large institutional parties indicate how the institutional capacity to the companies is very high. According to Jensen and Meckling (1976), if institutional ownership is getting higher, it makes the external control of the company stronger, so that it can reduce agency cost. The higher the institutional ownership of a company, the smaller the debt used to fund the company. This is due to supervision by other institutions such as banks and insurance on company performance.

In this study, to see the relationship between insider ownership and institutional ownership with debt policy, researchers also involved control variables. According to Cornelius (2010), the purpose of using variable control is that the relationship between insider ownership and institutional ownership with the debt policy be constant and not influenced by other variables. The control variables in this study are dividend payment, firm size, asset structure, profitability, and tax rate.

There are various reasons for choosing the control variable. in determining debt policy, insider ownership, namely managers who also as owners want to get dividends, and usually institutional owners also tend to expect dividends rather than capital gains, so dividend payments are also a matter of consideration for managers in determining debt. Furthermore, in determining debt policy, managers also consider the size of the company, because in general companies that have large size companies will have the flexibility and ability to obtain funds.

According to Brigham and Houston (2011), companies that have large assets can be used as collateral in obtaining debt. In determining debt policy, owners also see the company's ability to generate profits, because companies that have high profitability tend to use internal funds, namely retained earnings compared to external funds. According to Modigliani (1963), the use of debt can also reduce the amount of tax paid by the company, and the amount of tax rates is also a matter of consideration for managers in determining corporate debt.

Based on the theory and previous research, it can be formulated hypotheses are: (1) Insider ownership has a negative correlation with the debt policy of property and real estate companies on the Indonesian Stock Exchange by controlling dividend policy, size, assets, profitability and taxes.; (2) Institutional ownership has a negative correlation with the debt policy of property and real estate companies on the Indonesian Stock Exchange by controlling dividend policy, size, assets, profitability and taxes. 


\section{Methods}

Population in this study is all property and real estate company listed on the Stock Exchange Jakarta from 2012 to 2015. The sampling method using purposive sampling, with the criteria listed company for the period 2012-2015, the company publishes full financial statements during the observation period or after it is published on the Stock Exchange is accessible year 2012-2015, the availability of data on the amount of debt the company managerial ownership over the study period, institution during the study period. Based on the above criteria, 60 observations were selected. The data used are secondary data obtained from the Indonesian Capital Market Directory (ICMD).

\section{Definition of Operations and Measurement of variable}

\section{Debt policy}

Debt policy is the proportion that shows the use of debt in company financing decisions. Debt policy can be measured by Debt. Debt can be calculated by dividing the number of long-term debt (long-term debt + equity).

$$
D E B T=\frac{\text { long }- \text { term debt }}{\text { long }- \text { term debt }+ \text { equity }}
$$

\section{Ownership structure}

Ownership structures consist of insider ownership and institutional ownership. Insider ownership can be determined by comparing the number of shares held by the management with total outstanding shares and is calculated by the following formula: $\mathbf{( 9 9 \% )}$

$I N S D=\frac{\text { share by the management of the company s }}{\text { the number of shares of stock }}$

Institutional ownership (INST) represents the percentage of the ownership of shares by the institution. INST can be determined by comparing the number of shares held by institutions with the number of the company's outstanding shares and is calculated by the following formula:

$$
I N S T=\frac{\text { number of shares held by company }}{\text { the number of shares of stock }}
$$

\section{Variable Control}

The operational definition and measurement control variables for this study is as described below.

\section{Dividend Payment}

It can be seen by comparing the number of dividends paid to a net profit after tax and is calculated by the following formula:

\section{Firm Size}

$$
D P R=\frac{\text { Dividend }}{E B T}
$$

Can be known with total sales of natural log and is calculated by the following formula:

$$
\text { size }=\mathrm{LN} \text { Total Sales }
$$

Asset Structure can be seen by comparing the number of fixed assets to total assets of the company and is calculated by the following formula:

$$
\text { ASSET }=\frac{\text { Fixed Asset }}{\text { Total Assets }}
$$




\section{Profitability}

Profitability can be seen by comparing the company's total operating profit assets companies and is calculated by the following formula:

$$
\text { PROF }=\frac{\text { Operating Income }}{\text { Total Assets }}
$$

\section{Tax Rate}

Tax Rate can be seen by comparing the amount of tax paid by the earnings before taxes and is calculated by the following formula:

$$
\text { Tax Rate }=\frac{\text { Tax Paid }}{\text { EBT }}
$$

\section{Analysis Techniques}

This research uses a partial correlation. According to Cornelius (2010: 129) correlation analysis is an analysis that is used to express the degree of closeness of the relationship between variables and partial correlation analysis was used to test the relationship between two variables by issuing other variables (control variables) that influence the correlation.

\section{Results and Discussion}

\section{Descriptive Statistics}

Based on Table 1 (appendix) shows that the number of valid data is 60- firm-year during the period 2012- 2015. DEBT has minimum value is $0.86 \%$, the maximum value of $52 \%$, the average value of $20.14 \%$ and a standard deviation of $14.45 \%$. Insider ownership has the lowest value of $0.01 \%$, the highest value of $50.53 \%$, with an average of $4.71 \%$ and a standard deviation of $12.50 \%$. The minimum value of institutional ownership is $20.14 \%$, the maximum value is $93.21 \%$, the average $62.38 \%$, and the standard deviation is $18.97 \%$. Dividend payment has a minimum value of $0 \%$, the maximum value of $106.35 \%$, the average value of $14.14 \%$, and the standard deviation of $23.35 \%$. Firm size has the lowest value of 9.74 billion, the maximum value of $15.83 \%$, with an average value of $13.43 \%$, and a standard deviation of $1.76 \%$. The minimum value of the asset structure is $0.39 \%$, the maximum value of $86.64 \%$, the average value of $17.05 \%$, and a standard deviation of $21.81 \%$. Profitability has the lowest value of $-1.78 \%$, the highest value $30.30 \%$, With an average of $9.84 \%$, and a standard deviation of 6.36 . The tax rate has a minimum value of $0.04 \%$, the maximum value of $64.49 \%$, with an average value of $17.89 \%$, and the standard deviation of $12.44 \%$.

Table 1 Descriptive Statistics

\begin{tabular}{llrrrr}
\hline & N & Minimum & Maximum & \multicolumn{1}{c}{ Mean } & \multicolumn{1}{c}{ Std. Deviation } \\
\hline DEBT & 60 & 0,86 & 52 & 20,1378 & 14,44875 \\
\hline INSDR & 60 & 0,01 & 50,53 & 4,7117 & 12,49790 \\
\hline INST & 60 & 20,14 & 93,21 & 62,3755 & 18,97425 \\
\hline DPR & 60 & 0 & 106,35 & 14,1470 & 23,35940 \\
\hline SIZE & 60 & 9,74 & 15,83 & 13,4313 & 1,76298 \\
\hline ASSET & 60 & 0,39 & 86,64 & 17,0515 & 21,80791 \\
\hline PROF & 60 & $-1,78$ & 30,3 & 9,8395 & 6,35782 \\
\hline TAX & 60 & 0,04 & 64,49 & 17,0888 & 12,44104 \\
\hline $\begin{array}{l}\text { Valid N } \\
\text { (listwise) }\end{array}$ & 60 & & & & \\
\hline
\end{tabular}




\section{Partial Correlation Analysis}

According to Cornelius (2010: 129) correlation analysis is an analysis that is used to express the degree of closeness of the relationship between variables and partial correlation analysis was used to test the relationship between two variables by issuing other variables (control variables) that influence the correlation. Partial correlation analysis performed using SPSS. The result of partial correlation can be seen in Table 2 (appendix).

Table 2 Partial Correlation Analysis Test Results

\begin{tabular}{|c|c|c|c|c|c|}
\hline \multirow[t]{4}{*}{ Control Variables } & & & DEBT & INSDR & INST \\
\hline & & Correlation & 1000 & -157 & -0.011 \\
\hline & DEBT & $\begin{array}{l}\text { Significance (2- } \\
\text { tailed) }\end{array}$ & - & 0.253 & 0.937 \\
\hline & & Df & 0 & 53 & 53 \\
\hline DPR \& SIZE\& ASSET \& & & Correlation & -0.157 & 1000 & -0.644 \\
\hline \multirow[t]{5}{*}{ PROF \& TAX } & INSDR & $\begin{array}{l}\text { Significance (2- } \\
\text { tailed) }\end{array}$ & 0,253 & - & 0 \\
\hline & & Df & 53 & 0 & 53 \\
\hline & & Correlation & -0.011 & -0.644 & 1000 \\
\hline & INST & $\begin{array}{l}\text { Significance (2- } \\
\text { tailed) }\end{array}$ & 0.937 & 0 & - \\
\hline & & Df & 53 & 53 & 0 \\
\hline
\end{tabular}

\section{The Relationship between Insider Ownership and Debt Policy}

Table of correlation between insider ownership and debt policy with the variable control of dividend payment, firm size, asset structure, profitability and tax rate which has a correlation coefficient value of -0.157 . This shows that every increase in institutional by one unit and the control variable is considered constant, it will reduce the debt policy of property and real estate companies by 0.157 .

The first hypothesis in this study is that insider ownership has a negative correlation with the debt policy of property and real estate companies listed on the Stock Exchange with dividend payment, firm size, asset structure, profitability da tax rate as a control variable. Based on the correlation table, it is known that the insider ownership correlation coefficient is negative 0.157 with a significance of $0.253>0.05$. This means that the insider ownership has a negative and insignificant relationship with the debt policy of property da real estate companies with dividend payment, firm size, asset structure, profitability da tax rate as a control variable so that the first hypothesis is rejected.

Control variables are used in this study so that the relationship between insider ownership and institutional ownership with debt policy becomes constant and is not influenced by other variables not examined (Cornelius, 2010: 129). Control variables were chosen because the phenomenon in determining insider ownership debt policy is managers who also as owners want to get dividends, so dividend payments are also a consideration for managers in determining debt. Besides, in determining debt policy managers also look at the size of the company, because usually, companies that have large sizes will have the flexibility and ability to get funds.

According to Brigham and Houston (2011) in general, companies that have guarantees, it will be easier to get a loan, therefore determining the company's debt policy also looks at the structure of the company's assets. In determining the company's debt policy, the owner also sees the company's ability to generate profits, because companies that have high profitability tend to use internal funds, namely retained earnings compared to external funds. According to Modigliani (1963), the use of debt 
can also reduce the number of tax paid by the company, and the amount of tax rates is also a matter of consideration for managers in determining the company's debt. Theoretically, insider ownership is the percentage of share ownership by management that actively participates in corporate decision making. With the increase in insider ownership will cause the spread of risk so that managers feel directly as a result of the decisions taken. This causes managers to be careful in making corporate funding decisions through debt policy.

The results of this study indicate that the insider ownership of the company has a negative and not significant relationship with the company's debt policy with dividend payment, firm size, asset structure, profitability and tax rate as a control variable. This is because insider ownership in property and real estate companies is relatively small with an average of only $4.72 \%$, so managerial parties place more importance on their interests as managers than their interests as shareholders. With the importance of their interests as managers, managers less consider dividend payments that the owner wants, company size, asset structure, the ability of the company to generate profits and the percentage of taxes paid, because managers tend to be selfish. The results of this study are not in line with the agency theory proposed by Jensen (1976) which states that insider ownership has a negative correlation with debt policy.

This research is in line with previous research conducted by Devi (2008) and Abdullah (2009) which states that insider ownership does not a correlation with debt policy. The results of this study conflict with Ismiyanti and Hanafi's research which states that insider ownership has a positive and significant influence on debt policy.

\section{The Relationship between Institutional Ownership and Debt Policy}

The correlation table between institutional ownership and debt policy with a dividend payment, firm size, asset structure, profitability and tax rate that has a correlation coefficient value of -0.011 , shows that every increase in institutional ownership of one unit and control variable is considered constant, it will decrease the debt policy of property and real estate companies amounted to 0.011 .

The second hypothesis in this study is that institutional ownership has a negative correlation with the debt policy of property and real estate companies listed on the stock exchange with dividend payment, firm size, asset structure, profitability and tax rate as a control variable. Based on the correlation table, it is known that the institutional ownership correlation coefficient value is -0.157 with a significance of $0.937>0.05$. This means that the institutional ownership has a negative and insignificant relationship with the debt policy of property and real estate companies with dividend payment, firm size, asset structure, profitability and tax rate as a control variable. Therefore, it can be said that the second hypothesis is rejected. The control variable was chosen because the phenomenon of institutional owners in determining debt policy also pays attention to dividend payments in return for stock investments, besides that institutional owners also consider the size of the company, collateral assets, the company's ability to generate profits and tax payments by the company.

Institutional ownership does not correlate with the company's debt policy. The average institutional ownership in property and real estate companies is $62.38 \%$. The size of the institution's ownership makes it possible for institutions to conduct more effective supervision of company funding by considering dividend payments, company size, asset structure and the company's ability to generate profits and tax rates paid by the company, but institutions do not know the company's condition in a certain way. Who knows the condition of the company as a whole is a company manager. Therefore it is difficult for institutions to carry out effective supervision related to corporate funding.

The results of this study are in line with Devi (2008) and Abdullah (2009) who stated that institutional ownership does not correlate with debt policy. The results of this study are not in line with Ismiyanti and Hanafi (2003) which states that institutional ownership has a positive and significant correlation with debt policy. 


\section{Conclusion}

Based on the results and discussion, it can be concluded that insider ownership has no correlation with debt policy of property and real estate companies with a dividend payment, firm size, asset structure, profitability and tax rate as a control variable and Institutional ownership has no correlation with debt policy of property and real estate companies with a dividend payment, firm size, asset structure, profitability and tax rates as control variables.

\section{References}

Abdullah W. Djabid. (2009). Kebijkan Dividen dan Struktur Kepemilikan Terhadap Kebijakan Utang: Sebuah Perspektif Agency Theory. Jurnal Keuangan dan Perbankan, Vol. 13, No. 2 mei 2009, hal. 249-259.

Agrawal, A, and G Mandkeler. (1987). Large Shareholders and Monitoring of Managers: The case of anti Takeover Charter Amendements. Journal of Finance., pp. 823-827.

Brigham, EF. \& Joel F. Houston. (2011). Dasar-dasar Manajemen Keuangan. Jakarta: Salemba Empat.

Crutley, C \& Hansen. (1989). A test of the Agency Theory of Managerial Ownership, Corporate Leverage and Corporate Dividend. Financial Management(No

18). Hlm 36-46.

Cornelius, T. (2010). Step by Step SPSS 18 Analisis Data Statistik. Yogyakarta: Andi Offset

Devi Nurvida Avril Diana dan Gugus Irianto. (2008). Pengeruh Kepemilikan Manajerial, Kepemilikan Institusional dan Sebaran Kepemilikan terhadap Kebijakan Utang Perusahaan ditinjau dari Teori Keagenan. Emisi Vol. 1, April 2008:1-16.

Husnan, S. (2008). Manajemen Keuangan Teori dan Penerapan (Keputusan Jangka Panjang). Yogyakarta: BPFE.

Ismiyanti Fitri dan Hanafi. (2003). Pengaruh Kepemilikan Manajerial dan Institusional, Risiko, Kebijakan Utang dan Kebijakan Deviden: Analisis Persamaan Simultan. Simposium Nasional Akuntansi.

Jensen, M \& W. Meckling. (1976). Theory of The Firm and Managerial Behavior Agency Cost and Ownership Structure. Jurnal of Finance and Economics.

Kewon, A et al. (2008). Dasar-dasar Manajemen Keuangan. Jakarta: Salemba Empat.

Modigliani, F. Miller. (1963). Corporate Income Tax and Cost of Capital. American Review.

M. Syafrudin Hidayat. (2013). Pengaruh Kepemilikan Manajerial, Kebijakan Deviden, Struktur Aktiva, Pertumbuhan Penjualan dan Ukuran Perusahaan terhadap Kebijakan Utang. Jurnal Ilmu Manajemen. 